\title{
USF2 Gene
}

National Cancer Institute

\section{Source}

National Cancer Institute. USF2 Gene. NCI Thesaurus. Code C38369.

This gene plays a role in the transcriptional activation of target genes. It is involved in

DNA binding to a nucleotide sequence that is found in a variety of viral and cellular promoter regions. 